\title{
The Cultural and Economic Implications of Contemporary UK/European Co-production
}

\author{
As research on transnational cinema makes clear, films do not easily coincide \\ with national borders, but 'link people or institutions across nations' (Ezra and \\ Rowden 2006, 1). While Britain's strongest transnational links are with the US, it \\ has also developed production partnerships with its European neighbours. Each \\ year, British film companies lead-produce about fifteen co-productions with other \\ Europeans. But why do British filmmakers work with European partners, and \\ what are the implications of these partnerships for their film's cultural identity \\ and its box office performance? Through analysing a sample of recent \\ UK/European co-productions, this article suggest most British film companies \\ work with other Europeans for financial rather than creative reasons. At the same \\ time, UK/European co-productions are more 'culturally European' than other \\ categories of British film (i.e. domestic and inward investment features). While \\ this does not necessarily boost their popularity with European audiences, the \\ bigger budgets and better distribution links which co-production enables means \\ UK/European co-productions on average perform better in Europe than UK \\ domestic features. Co-production is therefore a useful strategy for getting British \\ films made and circulated within Europe, though this strategy is also thwarted by \\ a UK film policy orientated towards attracting higher value US inward \\ investment features.
}

Keywords: UK; Europe; co-production; film industry; transnational cinema.

\section{Introduction}

British films do not come more 'British' than The Queen (Stephen Frears, 2006). Peter Morgan's drama about Queen Elizabeth II's handling of the tragic death of Diana, Princess of Wales, not only takes as its subject one of Britain's key national institutions, but also depicts that institution coming to terms with the values of a new Britain, symbolised by the recent election of the New Labour government under the leadership of Prime Minister Tony Blair. But while the film's subject matter is emphatically 
British, its production history, like that of many contemporary British films, is more transnational. The Queen was produced by Manchester-based Granada Productions in co-production with France's Pathé Pictures and Italy's BIM Distribuzione. It was partly shot in Paris and involved an international cast and crew, including a Brazilian cinematographer, an Irish costume designer, and a French composer.

Such examples illustrate the problems of pigeon-holing films by nationality. Although films have a designated country-of-origin for legal or financial purposes (e.g. paying taxes or receiving subsidies), they also 'link people or institutions across nations' (Ezra and Rowden 2006, 1). A film may be defined as 'British', for example, if it passes a 'Cultural Test' set by the British Film Institute (BFI), the lead organisation responsible for the cultural, creative and economic aspects of film in the UK. ${ }^{1}$ However, as Higson $(2011,68)$ explains, most contemporary British films are also transnational enterprises:

\footnotetext{
At the level of funding and production, they draw money, actors and creative personnel from different national contexts. At the level of representation, their narratives deal with characters from different places interacting with each other in a variety of settings, as they journey between different countries and cultures.... At the level of exhibition and reception, too, such films are shown at film festivals and in cinemas around the world.
}

While Higson defines transnational films in terms of their production histories, their narrative concerns and their exhibition and reception, transnational cinematic relationships also take on particular forms. Mette Hjort (2009), for example, identifies nine specific types of transnational production, including: 
- Affinitive transnationalism - the tendency to collaborate with those who share similarities with us in terms of language, ethnicity, values, practices and institutions;

- Opportunistic transnationalism - where monetary factors dictate the selection of production partners; and

- Globalising transnationalism - where big budget special effects and a star cast are used to attract a global audience and recuperate high production costs.

Using a similar approach, but also taking into account the film's aesthetics, ethics and reception as well as its production process, Deborah Shaw (2013) goes even further by identifying fifteen types of transnationalism. There are undoubtedly other ways of categorising transnational relationships, but the key point is that we need to pay close attention to the particular cultural, political and economic contexts within which these relationships are configured (see Higbee and Hwee Lim 2010).

Britain's strongest transnational links - at the level of production, exhibition and reception - have historically been with the United States, reflecting Hollywood's longstanding dominance of the global film industry (Townsend 2014). Of the $£ 1,068.6$ million spent on UK film production in $2013,70 \%$ went on UK films made with US inward investment (BFI 2014a, 181). According to the BFI Statistical Yearbook (2014a), American films accounted for $71 \%$ of British cinema admissions in the period 2001 to 2013 (although we have to keep in mind that such films also have their own transnational elements). By contrast, British films accounted for $25 \%$ of admissions, though three-quarters of these were for British films backed by US studios, such as the Harry Potter and James Bond franchises.

At the same time, Britain also has important transnational links with its 
European neighbours, particularly at the level of production. Between 2003 and 2013, the UK averaged 19.5 majority co-productions and 34.7 minority co-production (BFI 2014a, 182). Most of these films (about fifteen majority UK co-productions per year) involved European partners. Altogether, co-productions averaged 20.0\% of the films produced in the UK and 5.1\% of total production spend (BFI 2014a, 181-2).

The British film industry has a long history of collaboration with Europe. UKEuropean co-productions first emerged with the 'Film Europe' movement of the 1920s and early-1930s (Higson and Maltby 1999). In 1965, Britain signed its first coproduction treaty with France, followed by a second in 1967 with Italy, and a third in 1974 with West Germany (Smith 2010). However, the total number of co-productions made during this period remained very small at about three per year - about $3 \%$ of total British film output. ${ }^{2}$ According to Justin Smith (2010, 52), Britain's ambivalence over full membership of the European Community meant that these treaties proved "ineffectual in promoting co-productions", even if they "gave rise to a co-production slate which, if limited in number, was eclectic and, occasionally, successful".

With the increasing move towards European integration in the late-1980s and early-1990s, Britain's cinematic relations with Europe intensified. In 1991, the UK joined the European Union's (EU) MEDIA programme, which supports the distribution of European film, and in 1992 it signed the European Convention on Cinematographic Co-production, an agreement between the members of the Council of Europe designed to promote multilateral co-productions (i.e. co-productions involving at least three coproducers in three different countries who are parties to the Convention). ${ }^{3}$ Meanwhile, British Screen Finance, an independent industry-funded body for the audiovisual sector, launched its European Co-production Fund, while in 1992 the UK joined Eurimages, 
the Council of Europe's co-production fund, though left the latter after only four years due to government budget cuts (Dawntrey 1995).

But while the history of UK/European co-production agreements is welldocumented (e.g. Smith 2010; Jäckel 1996), there has been little research on Britain's more recent production links with Europe. As Smith $(2010,65)$ puts it, "One wonders whether - despite further European integration - post-unification, British cultural policy today remains as Janus-faced as ever, ambivalent in its view across both the Channel and the Atlantic."

This article addresses this gap in the literature by examining the cultural and economic implications of UK/European co-production as a particular form of transnational activity. ${ }^{4}$ After briefly reviewing in section one the literature on coproduction, section two examines some of the recent trends and policy issues affecting UK/European co-production. Section three then analyses a random sample of recent UK/European co-productions in order to understand why British filmmakers choose to collaborate with European partners and how this affects the cultural identity of their films. Finally, section four examines the box office performance of UK/European coproductions in comparison to other types of British film (i.e. UK domestic films and UK/US inward investment features), and considers whether British films with high levels of European creative input are more popular with European audiences. ${ }^{5}$

The article draws primarily on quantitative data from public databases, such as the BFI database of films produced in the UK (2003-2013) ${ }^{6}$ and the European Audiovisual Observatory's LUMIERE database. ${ }^{7}$ It also uses the BFI's 'Cultural Test' for film to quantify how much European creative input goes into UK/European coproductions. This quantitative approach is deemed more appropriate to the aims of the 
article than a more qualitative methodology, because it allows one to compare a large number of films and identify broad trends and categories. At the same time, some of the potential problems associated with this approach are noted alongside the findings. The methodology is described in more detail in sections three and four.

\section{Literature review}

The BFI defines a co-production as: 'A film made by companies from more than one country, often under the terms of a bilateral co-production treaty or the European Convention on Cinematographic Co-production' (BFI 2014a, 241). ${ }^{8}$ It further differentiates between 'majority' co-productions, 'in which the UK investment is the largest single national investment,' and 'minority' co-productions, 'in which at least one other country made a larger investment than the UK' (BFI 2014a, 182). Officially certificated co-productions qualify as 'British' films, and so are eligible for UK film tax relief and other subsidies. However, they are generally distinguished from 'domestic features', films made by a UK production company that is 'produced wholly or partly in the UK', and 'inward investment features', which are 'substantially financed and controlled from outside the UK and which [are] attracted to the UK by script requirements (e.g. location) and/or the UK's filmmaking infrastructure and/or UK film tax relief' (BFI 2014a, 242-3). The latter are similar to co-productions in the sense that they involve a partnership between a British and foreign film company (usually one of the major Hollywood studios). However, as the phrase 'substantially financed and controlled' indicates, inward investment features involve far less parity between these partners. Moreover, they are not subject to an official co-production treaty, which will specify the minimum level of creative and financial input (typically 20-30\% of the 
budget) each partner must contribute for the film to be treated as a 'British' film.

Instead, inward investment features must pass the BFI's 'Cultural Test' in order to qualify as 'British' (see section three).

Morawetz et al. (2007) distinguish between three broad types of co-production. Firstly, there are co-productions which come together predominantly for creative reasons, such as a cross-border story (e.g. Ken Loach's Land and Freedom (UK/Spain/Germany, 1995), about a young English communist who travels to Spain to fight in the Spanish Civil War). These are typically low-to-medium budget art-house films. Secondly, there are financially-driven co-productions, which are only structured as co-productions so the filmmakers can raise the necessary finances to get the picture made, even if this means adjusting the film's creative elements (e.g. in an earlier Loach film, Fatherland (UK/France/West Germany, 1986), the role of a Dutch journalist was changed to a French character in order access French co-production funds). These are also usually low-to-medium budget films financed on a one-off basis. Finally, there are capital-driven co-productions, where a film is structured as a co-production largely to enable investors to exploit benefits like tax credits. These are typically medium-to-high budget films aimed at mainstream international audiences. They usually form part of a slate of films and are often distributed by Hollywood studios. It is worth noting that Morawetz et al.'s description of 'creatively-driven' co-productions broadly corresponds to what Hjort calls 'affinitive transnationalism' (see introduction), while 'financiallydriven' and 'capital-driven' co-productions resembles 'opportunistic transnationalism' and 'globalising transnationalism' respectively.

Research suggests that most co-productions are financially- rather than creatively-driven. For example, a survey of Canadian and European co-production partners in the 1990s by Hoskins et al. (1995) found that the opportunity to pool 
financial resources was seen as the most important benefit, followed by access to foreign incentives and subsidies and access to the partner's market. Meanwhile, cultural goals, such as filming in a desired location, ranked relatively low on the list of priorities. Similarly, Pardo $(2007,22)$ calculates that the majority of co-productions made in Spain between 2000 and 2004 were 'designed on a strictly financial basis, without demanding necessarily a creative or cultural exchange'. Only a quarter could be described as 'multicultural co-productions in the proper sense of the term' (Pardo 2007, 22).

But even though most co-productions are financially-driven, the logistics of coproduction inevitably have consequences for a film's cultural identity. Official coproduction treaties often specify that each co-production partner must have a creative input in the film which is proportional to their financial investment, even if this is not always appropriate to the film's narrative. ${ }^{9}$ This is led some to associate co-productions with the derogatory term 'Europuddings' - films which unconvincingly blend together different cultural and linguistic elements or which downplay those differences, only to appear bland and indistinct (see Liz 2005). Others, however, welcome the transnational cultural exchange which co-production enables. Jäckel (2007: 29), for example, notes in reference to the work of the Franco-German broadcaster Arte, co-production can result in "outstanding examples of European works addressing cultural diversity and the (problematic) integration of individuals, or groups of individuals, within a wider community".

Co-production may also affect a film's box office performance and how well it travels. A recent study by Kanzler (2008), for example, found that European coproductions sold 2.7 times more cinema tickets within the European Union (EU) than purely domestic features and were also released in twice as many territories. However, 
it is unclear whether co-productions travel better because their transnational cultural identity ensures they appeal to a broader audience, or whether it is because they enjoy better access to their partner's market. In their study of the regional circulation of Scandinavian co-productions, Bondebjerg and Redvall $(2013,8)$, for example, note that, 'Co-production probably is an important factor for the internationalisation of films, but other elements such as genre, star quality and distribution play a central one'.

\section{Production trends and policy issues}

According to the BFI's Statistical Yearbook (2014, 180-2), the UK produced 106 coproductions in 2003 (of which 21 were majority UK co-productions) [figure 1], contributing $£ 158 \mathrm{~m}(14 \%)$ to the total value of UK film production [figure 2]. Although not all of these were UK/European co-productions, the BFI database of films produced in the UK (2003-2013) suggests that 19 of the 21 majority UK co-productions involved European partners. ${ }^{10}$ Germany was Britain's most frequent co-production partner with eight films, followed by France (4), Spain (3) and Romania (3).

In the decade following 2003, the total number of UK co-productions slumped by $66 \%$ from 106 to 37 per year (BFI 2014a, 180-2), while their contribution to the total value of UK film production likewise fell from $£ 158 \mathrm{~m}(14 \%)$ to just $£ 54 \mathrm{~m}(5 \%)$. The fall in the number of minority UK co-productions was particularly stark - from 85 to 17 per year. At the same time, the number of majority UK co-productions remained fairly stable at 20 per year. Of these, 16 involved European partners, including Germany (5), France (5), Italy (3) and the Netherlands (3).

The decline in the number of UK co-productions in the decade from 2003 to 2013 can be attributed to changes in UK film policy. Between 2002 and 2004 the 
British government tightened the co-production certification requirements in order to close several loopholes which were being exploited to provide tax avoidance of various kinds (Hill 2012, 345). Then in 2007, it introduced a new system of tax relief which required co-productions to spend at least $25 \%$ of their budget in the UK to qualify. Under this new system, tax relief could only applied to goods and services 'used and consumed' in the UK. While these reforms were broadly welcomed by the industry, some complained that the 'used and consumed' rule made the UK a less desirable coproduction partner. In written evidence to the House of Lords Select Committee in 2010, Mike Downey of the production company Film and Music Entertainment (F\&ME), for example, claimed the new tax system had cut his company's revenue in half and made it 'unworkable' for British producers to be involved in films made abroad. As he explained:

\begin{abstract}
Co-production with Europe was always the way of having one's in-house British films supported - if that could be reciprocated. Now we suffer from the problem that we can't make the tax credit work for our partners so we lose any hope for reciprocal investment from Europe. This means that the number of productions and specifically European co-productions are mostly excluded from the possibilities of their tax credit. (Downey quoted in House of Lords 2010, 553).
\end{abstract}

The lack of public funding designated specifically for co-production has further depressed the number of UK co-productions. Schemes established in the 1990s such as Eurimages and British Screen's European Co-Production Fund are no longer available to British filmmakers. As Simon Perry (2014), head of the producers' association Ateliers du Cinéma Européen (ACE), claimed in a recent column for the industry press: 'Non-membership of the pan-European fund Eurimages probably does most to make Britain the co-production partner-of-last-choice within Europe'. Arguably, linguistic and cultural differences and Britain's semi-detached relations with the EU have also 
hampered production ties with Europe, though to what extent is difficult to say.

As a consequence of these factors, Britain co-produces far fewer films than its European neighbours. According to the European Audiovisual Observatory's report on World Market Trends (2004-2014), the UK averages 18 majority co-productions per year, compared with 54 in France, 28 in Spain and 25 in Germany [figure 3]. Of the 'Big Five' European film producing countries, only Italy produces fewer majority coproductions than Britain, with an average of 16 per year. Furthermore, few British film companies make more than one or two co-productions, which suggests that most UK/European co-productions are opportunistic rather part of a long-term strategy. Notable exceptions include Ken Loach's production company Sixteen Films, which has developed strong relationships with Spain's Tornosol Films, Germany’s Road Movies and France's Why Not Productions (Jones forthcoming), and Glasgow-based Sigma Films, which has developed a long-standing relationship with Denmark's Zentropa Entertainment (Murray 2012). ${ }^{11}$ Director Peter Greenaway also stands out as a British filmmaker who has also consistently worked with European partners.

\section{Creative input and cultural identity}

Although the total number of UK co-productions has declined over the past decade, the number of UK/European co-productions has remained fairly constant at about fifteen per year. These films represent a small but significant part of the UK film industry. In this section I want to examine in more detail why certain British filmmakers collaborate with European partners and how this affects the cultural identity of their films.

To answer these questions, a test was devised to evaluate how much creative input European partners have within UK/European co-productions. Firstly, a list of 
recent UK/European co-productions was created using the BFI database of films produced in the UK (2003-2013). This was then cross-checked against a separate list of UK/European co-productions for the period 2005 to 2012 created using the LUMIERE database, so that any anomalies were removed. ${ }^{12}$ From this final dataset of 64 UK/European co-productions, 30 films were randomly selected. Using an adapted version of the BFI's Cultural Test for film as a guide (see below), the amount of creative input the European co-production partners had in the film was quantified.

The Cultural Test is the official test used to determine whether a film (other than those films made under an official co-production treaty) is 'culturally British' and therefore eligible for UK tax relief and/or public funding (BFI 2014b). Up to 31 points can be awarded in each of the following categories:

- Cultural content (up to 16 points) - the setting (4), lead characters (4), subject matter (4), and language of the film (4);

- Cultural contribution (up to 4 points ) - representing the nation's creativity (1), heritage (1) or cultural diversity (2);

- Cultural hubs (up to 3 points) - the country where principal photography (2) and post-production (1) took place; and

- Cultural practitioners (up to 8 points) - the nationality of the director (1), scriptwriter (1), producer (1), composer (1), lead actors (1), cast (1), key staff (1), and crew (1). ${ }^{13}$

Using this scoring system to quantify creative input may seem somewhat reductive. Questions like 'does the film represent the nation's creativity?' are certainly difficult to answer objectively (which is why the 'cultural contribution' category must be treated with particular caution). It is also worth noting that the scoring system is heavily 
weighted toward 'cultural content' and 'cultural contribution', which together represent a maximum 20 points, with the 'cultural hubs' and 'cultural practitioners' categories yielding only a possible 11 points (see Higson 2011, 56-66). Nevertheless, as Pardo (2007) has demonstrated using a similar method in relation to Spanish co-productions, this approach does allow us to compare a large number of films and possibly identify broader trends and categories within a reasonable margin of error.

This method of analysis suggests that on average only about $16 \%$ (or 5.5 out of the total 31 points) of the creative input which goes into UK/European co-productions can be attributed to the European partner(s) [figure 4]. Given this low percentage, it seems likely that most European partners were chosen for financial rather than creative reasons. This goes along with the findings of Hoskins et al. (1996) in relation to Canadian/European co-productions in the 1990s and Pardo (2007) in relation to Spanish co-productions in the early-2000s and suggests that most UK/European co-production are examples of what Hjort calls 'opportunistic transnationalism'. The only category where European partners generally do have significant creative input is the 'cultural hubs' category. This can be explained by the fact that production companies are often required to do some of their filming in their partner's country in order to access financial incentives. The heist movie Flawless (Michael Radford, UK/Luxembourg, 2007), for example, was partly filmed in the tax haven of Luxembourg, even though the story is entirely set in 1960s London. In a similar vein, interiors for the British romantic comedy The Best Man (Stefan Schwartz, UK/Hungary/Germany, 2005) were shot in Budapest so the producers could benefit from Hungary's 20\% tax rebate credit and the country's lower labour costs, even though no part of the story is Hungarian (The Writing Studio 2015).

About a fifth of the UK/European co-productions analysed could be described as 
creatively-driven partnerships, where the partner was clearly chosen for script requirements or other creative reasons. One example is the thriller 360 (Fernando Meirelles, UK/Austria/France/Brazil, 2011) about interconnected romantic life in the twenty-first century. The story starts in Vienna, weaving stories set in Paris, London, Bratislava, Rio, Denver and Phoenix into a single narrative. As such, it involved Austrian, French and Brazilian partners. Similarly, L'illusioniste (Sylvian Chomet, UK/France, 2009), an animated tale about a French magician who travels to a remote Scottish island in the 1950s, involved a French partner, just as Joy Division (Reg Traviss, UK/Hungary/Germany, 2006), a Cold War thriller about a German teenage orphan sent to London to spy for the KGB, involved a German partner.

Despite the relatively low level of creative input from their European partners, UK/European co-productions generally have more transnational elements than other types of British film [figure 5]. Comparison with a random sample of 30 UK domestic features and $30 \mathrm{UK} / \mathrm{US}$ inward investment features, for example, suggests that UK/European co-productions have the highest proportion of foreign creative input $39 \%$ compared with $17 \%$ for UK domestic features and $26 \%$ for UK/US inward investment features. While some of this foreign creative input can be attributed to their European partners, much of it comes from other sources. For example, the German coproduced psychological thriller Berberian Sound Studio (Peter Strickland, UK/Germany, 2012) features Italian characters and settings. Similarly, the German coproduced drama The Last King of Scotland (Kevin Macdonald, UK/Germany, 2006) is largely set in Uganda and features British, American and Ugandan characters. In both cases the film's foreign creative input has no direct link with the co-production partner.

Almost half the foreign creative input (22\% of the total) which goes into UK/European co-productions comes from European sources. Indeed, about 6 of the 30 
films analysed were found be at least $50 \%$ European in terms of their cultural content (e.g. settings, characters, subject matter and language). However, it is worth pointing out that few of these films engage with contemporary Europe. Half are set in the recent past, including Belle Époque Paris (Chéri, 2009), post-World War II Italy (Fade to Black, 2006) and 1950s Paris and Scotland (L'illusioniste, 2009). Others draw inspiration from Europe's cultural heritage. The animations Peter and the Wolf (Suzie Templeton, UK/Poland/Switzerland/Norway, 2006) and The Flying Machine (Martin Clapp and Geoff Lindsey, UK/Poland/Norway, 2011), for example, were inspired by the music of Prokofiev and Chopin respectively. Porter $(1984,8)$ notes in relation to earlier examples of European co-production, '[t]his emphasis on European cultural heritage and high culture... at the expense of what life is like in Europe today' is characteristic of European co-production.

America is the other major source of foreign creative input (11\% of the total). Indeed, in terms of their cultural content, UK/European co-productions feature twice as many American elements (e.g. characters, settings and subject matter) as UK/US inward investment films. The black comedy Guy X (Saul Metzstein, UK/Canada/Iceland, 2005), for example, portrays an American soldier (Jason Biggs) who is mistakenly posted to an Arctic military base. Similarly, the romantic comedy Love and Other Disasters (Alek Keshishian, UK/France, 2007) features the late Brittany Murphy as an American intern who tries to help her British flatmate (Matthew Rhys) find love.

Some of the UK/European co-productions analysed also combine American cultural elements with European elements to produce a kind of 'transatlantic' hybrid (c.f. Townsend 2014). Chéri (Stephen Frears, UK/France/Germany, 2009), for example, tells the story of a love affair between an ageing Parisian courtesan and her best friend's son. The film, adapted from a novel of the same name by the French author Colette, is 
set in France and involved a French production crew. Yet the role of the Parisian courtesan and her best friend Madame Peloux are played by US actresses Michelle Pfeiffer and Kathy Bates, both of whom speak with American accents throughout the film. As one reviewer opined: 'the film opts for a kind of stilted no-where, which has the effect of dissipating the Gallic spell that its trappings strive so hard to generate' (Cox 2009). The use of American actors, characters and subject matter within UK/European co-productions can be seen as an example of what Hjort calls 'globalising transnationalism', whereby filmmakers adopt mainstream Hollywood production strategies (e.g. the use of big-named stars) to appeal to a global audience.

But although UK/European co-productions involve creative input from European, American and other foreign sources, the majority could still be classified as 'culturally British'. It is estimated that at least 18 of the 30 would qualify as 'British' under the Cultural Test (and even this is probably an underestimation due to the decision to take account of accent and dialogue). ${ }^{14}$ These include films such as The Duchess (Saul Dibb, UK/France/Italy 2008) and Route Irish (Ken Loach, UK/France/Italy/Belgium/Spain, 2010), which between them represent two of the dominant strands in culturally British filmmaking - heritage drama and social realism (see Higson 2011). The fact that these films were structured as co-productions rather than UK domestic features further strengthens the claim that British filmmakers enter into partnerships with other Europeans primarily for financial rather than creative reasons. Sixteen Films, the London-based production team behind Ken Loach's Route Irish, for example, has established a strong partnership with France's Why Not Productions and Wild Bunch, allowing them to make pictures which would struggle to be made on UK financing alone (Jones forthcoming). As interviews with the production staff at Sixteen Films have confirmed, these partners have had minimal creative input - 
as a director known for tackling politically contentious subject matter, Loach will only work with co-producers who allow him complete creative freedom - though they nevertheless benefit from production fees and pre-sales as well the kudos of having an award-winning director on their slate.

Even so, none of the UK/European co-productions analysed could claim to be completely 'culturally British'. Even those films whose cultural content was determined to be $100 \%$ British (e.g. Dreams of a Life, The Mighty Celt, Jump, Flawless and The Duchess) are still ambiguous in this regard. The documentary Dreams of a Life (Carol Morley, UK/Ireland, 2011), for example, traces the life of a Londoner of Ghanaian heritage, whereas The Mighty Celt (Pearse Elliott, UK/Ireland, 2005) and Jump (Kieron J. Walsh, UK/Ireland, 2012) are both set in Northern Ireland, where notions of 'Britishness' are highly contested. Using quantitative measures to determine a film's cultural identity is also skewed by how much weight one places on elements like the nationality of the director or lead actors (each of which account for only one point in the culture test). The spy thriller Tinker Tailor Solider Spy (Tomas Alfredson, UK/France/Germany, 2011), for example, would score highly in the Cultural Test because its cultural content is mostly British (although part of the action is also set in Hungary, Turkey and Russia) and it was made by a primarily British cast and crew. However, the film is described by producer Tim Bevan as 'a very European movie' because of the involvement of Swedish director Tomas Alfredson and Dutch-Swedish cinematographer Hoyte van Hoytema (Tutt 2011). This is a reminder that a film's cultural identity is not a fixed or objective category, but may be interpreted differently by policymakers, industry players or audiences.

It is also worth mentioning that none of the UK domestic features or UK/US inward investment features analysed could claim to be $100 \%$ 'culturally British' either. 
A Cock and Bull Story (Michael Winterbottom, UK, 2005), the UK domestic feature with the highest level of British creative input, had a Danish cinematographer (Marcel Zyskind), while Kinky Boots (Julian Jarrold, UK/US 2005), the most 'culturally British' of the UK/US inward investment features, had an Australian lead actor (Joel Edgerton) and Danish cinematographer (Eigil Bryld), not to mention American financial backing. What this underlines is the inherently transnational nature of contemporary British filmmaking, particularly at the level of production, where money, actors and creative personal are drawn from across national borders.

\section{Performance and circulation}

Having examined why certain British filmmakers choose to collaborate with European partners and how this affects the cultural identity of the film, I turn now to consider how this impacts upon the film's box office performance. In particular, I want to establish whether UK/European co-productions with high levels of European creative input are more popular with European audiences.

As noted in the literature review, research by Kanzler (2008) shows that European co-productions travel better within Europe than purely domestic films, though the reasons for this are not entirely clear. My own analysis of the theatrical admissions for a dataset of 449 British films (2005-12) created using the BFI and LUMIERE databases verifies this claim. ${ }^{15}$ Firstly, UK/European co-productions are more likely to be released outside the UK $-81 \%$ were screened in mainland Europe, compared with only $59 \%$ of UK domestic features. Secondly, UK/European co-productions are distributed more widely, with an average circulation of 8.9 territories out of the 36 European territories surveyed, compared with 6.3 territories for domestic UK features 
[figure 6]. Thirdly, UK/European co-productions attract on average 14 times as many admissions in mainland Europe as UK domestic features, with 76,970 admissions (median value) compared to 11,290 admissions [figure 7]. Fourthly, mainland Europe accounts for $74 \%$ of the total admissions for UK/European co-productions compared with $55 \%$ of total admissions in the case of UK domestic features.

Yet it is also worth pointing out that the performance of both UK/European coproductions and UK domestic features is completely overshadowed by UK/US inward investment features. These are released in 15.6 territories on average and attract nearly ten times as many admissions as UK/European co-productions, with an average (median value) of 735,719 admissions in mainland Europe. Furthermore, in contrast to Kanzler's study, the analysis shows that UK domestic features actually perform slightly better than UK/European co-productions in British cinemas, with 14,232 admissions (median value) compared to 11,290 admissions.

Why do UK/European co-productions perform better in mainland Europe than UK domestic features, but worse in British cinemas? Is it because they have higher levels of European creative input, or is it due to other factors, such as their budget or distribution links? To answer these questions, the theatrical admissions for my random sample of $30 \mathrm{UK} /$ European co-productions were analysed in more detail. This analysis found no real correlation between the level of European creative input and the film's performance in mainland Europe. Some of the films which could be described as ‘culturally European' (e.g. Chéri, L’illusioniste, 360) performed relatively well in mainland Europe, but equally many of the best performing films (e.g. Tinker Tailor Soldier Spy, Solomon Kane, The Duchess) were ones which would pass as 'culturally British'. 
However, closer analysis reveals that about half the UK/European co-

productions analysed performed better than average within their partner's territory. This is particularly the case with creatively-driven co-productions, where the co-production partner was clearly chosen for script requirements or other creative reasons. Thus the Majorca-based Four Last Songs (Francesca Joseph, UK/Spain, 2007) performed best in Spain; 360, which is partly set in Vienna, performed particularly well in Austria; and the French-influenced films Chéri and L'Illusioniste achieved their highest penetration rates (defined as admissions per head of population) in France. Moreover, certain films performed well in the 'home' territories of their cast and crew. Tinker Tailor Solider Spy, for example, enjoyed a particularly high penetration rate in Sweden, seemingly because of the involvement of Swedish director Tomas Alfredson.

However, not all the UK/European co-productions in the sample analysed performed well in their partner's territory. The Italian-set Fade to Black (Oliver Parker, $\mathrm{UK} / \mathrm{Italy} / \mathrm{Serbia})$ was not even released in Italy, as was also the case vis-à-vis Germany for the partly German-set thriller Joy Division. Similarly, Berberian Sound Studio had no cinema release in either the territory of its German co-production partner or in Italy, where the film is set. Indeed, about a quarter of the films analysed were not even theatrically screened in their partner's territory (though they may have received a television or DVD release). In the case of Fade to Black and Joy Division this may be because this films were made for British audiences (as evidenced by the fact they were shot in English), even though they were partly set in Italy and German respectively.

A film's cultural identity therefore appears to have a noticeable but inconsistent effect on how well it performs in the territories affiliated with that identity. However, what appears to make most difference to the performance of UK/European coproduction is the film's budget. Analysis of my large dataset of 449 British films reveals 
a strong positive correlation (Pearson's $r=0.83$ ) between budget size and theatrical admissions. ${ }^{16}$ This is presumably because bigger budget films can attract larger audiences through higher production values, better-known stars and wider publicity. The UK/European co-productions in the dataset have a median average budget threeand-a-half times that of UK domestic films ( $\$ 3.6 \mathrm{~m}$ compared with $\$ 1.0 \mathrm{~m})$. This is partly because co-production allows film companies to secure financial resources, subsidies and tax relief from their partner's territory. For example, $61 \%$ of the UK/European co-productions in the dataset had received some form of public investment, compared with only $44 \%$ of the UK domestic films. Almost a third had received some form of subsidy from at least one European public investor.

Genre is another factor which helps explain why UK/European co-productions circulate better than UK domestic features. Analysis of all the British films in the dataset shows that certain genres of (notably adventure, fantasy and family films) are significantly more popular with mainland European audiences than with British audiences. ${ }^{17}$ By contrast, comedies do better in the UK than in the rest of Europe, presumably because humour is often culturally-specific. This is corroborated by a recent European Commission $(2014,183)$ report on European film audiences, which confirmed that animation, family and adventure films travelled best within Europe, while comedies travelled least well. Adventure, fantasy and family films account for $10 \%$ of the UK/European co-productions in the dataset, compared with $4 \%$ for the UK domestic features. Equally, $10 \%$ of the UK/European co-productions in the dataset are comedies, compared with $18 \%$ of the UK domestic features, which perhaps explains why UK domestic features perform better in the UK market.

Finally, there is the role of 'gatekeepers' such as sales agents and distributors to consider. About $29 \%$ of the UK/European co-productions analysed have a European 
sales agent, compared to only $12 \%$ of domestic UK features. This is important because European sales agents often enjoy better links with distributors and exhibitors on the Continent than their British competitors. They also make it more likely that UK/European co-productions will receive distribution aid from the EU's MEDIA programme, which supports the cross-border circulation of non-national European films. About $47 \%$ of the UK/European co-productions in the dataset received MEDIA distribution support, compared with $29 \%$ for UK domestic features. On average UK/European co-productions received $€ 291,208$ through scheme compared with $€ 220,140$ for UK domestic features. ${ }^{18}$ This funding towards distribution costs can be crucial for the circulation of British films in mainland Europe. A simple linear regression analysis of the relationship between MEDIA distribution support (dependent variable) and theatrical admissions (independent variable), for example, shows that for every $€ 1$ of MEDIA distribution support a British film receives it can expect to gain 2.8 extra ticket sales within the European market.

\section{Conclusion}

What conclusions can be drawn about Britain's transnational links with the rest of Europe? For a start, it is clear that those links are most significant at the level of UK/European co-production. Although the total number of UK co-productions has declined over the last decade, the number of UK/European co-productions has remained fairly stable at about fifteen per year. As with earlier studies by Hoskins et al. (1996) in relation to Canadian/European co-productions and Pardo (2007) in relation to Spanish co-productions, it is also clear that most British production companies work with European partners primarily for financial rather than creative reasons. Only a fifth of the UK/European co-productions analysed could claim to be creatively-driven co- 
productions. Thus Britain's transnational cinematic relationship with the rest of Europe is more characterised by what Hjort calls 'opportunistic transnationalism' than 'affinitive transnationalism'. British film companies are often prepared to the take advantage of the financial opportunities which comes from working with European partners, but there is little desire to collaborate with other Europeans purely out of a shared sense of European identity. Nevertheless, UK/European co-productions do generally involve higher levels of European creative input and are more 'culturally European' than other types of British film. While this does not always make them more appealing to European audiences, it does mean they have higher budgets and better links with European distributors. These factors help ensure that UK/European coproductions generally perform better in mainland Europe than UK domestic features.

Britain's transnational links with its European neighbours therefore have many positive benefits. They allow independent films which might otherwise struggle for financing to be produced and distributed across Europe, thereby enabling a greater degree of transnational cultural exchange than might otherwise be the case. Indeed, it could be argued that by making British films more ‘culturally European', UK/European co-production goes some way towards deepening Britain's cultural affinities with the rest of Europe. More tangibly, UK/European co-productions generate higher revenue: they are more likely to be released outside the UK, are shown in more European countries and have higher European admissions than purely domestic UK films. And in most cases they involve little or no cultural or artistic compromises.

Yet Britain's links with Europe are also clearly frustrated by UK film policy. The criteria for UK tax relief and the lack of any specific financial subsidies for coproductions make Britain a less attractive partner than other European countries. The overriding success of films backed by US inward investment means that most British 
production companies look to America rather than Europe for transnational support. Some argue it would be better for UK/European co-productions to be conducted on an ad hoc basis outside the conditions of specific bilateral treaties, but while this may offer more flexibility and less chance of cultural compromise, it would make them ineligible for financial incentives (e.g. tax relief and subsidies) in their partner's territory, which, as we have seen, is one of the main reason why UK filmmakers rely on co-production partners in the first place.

Recent reforms to the UK film policy offer a better way forward. In April 2013, the BFI committed up to $£ 1 \mathrm{~m}$ per annum to encourage minority UK co-productions. In December 2013, the UK government announced plans to lower the minimum UK spend for British qualifying films from 25\% to 10\% (Macnab 2013). And in January 2015 the Cultural Test for film was revised to allow creative input from any EU member state. So, for example, points are now awarded for films set not only in the UK, but other European countries as well. But what would boost UK/European co-productions more than anything would be for Britain to re-join the Eurimages scheme (which it left in 1996 due to government budget cuts). Given that UK/European co-productions are 14 times more successful on average at the European box office than purely domestic UK features, it is likely that the cost of re-joining Eurimages would be off-set by the increased revenue for British film exports. Even in the context of renewed fiscal constraint in the UK and scepticism towards European institutions, there is a strong pragmatic economic case for renewing this important link with Europe.

\section{Acknowledgements}

This work comes out of the 'Mediating Cultural Encourages through European Screens' (MeCETES) project. MeCETES has received funding from the Humanities in the European Research Area (HERA) Joint Research Programme (www.heranet.info) under grant agreement 
number 291827. HERA is co-funded by AHRC, AKA, BMBF via PT-DLR, DASTI, ETAG, FCT, FNR, FNRS, FWF, FWO, HAZU, IRC, LMT, MHEST, NWO, NCN, RANNÍS, RCN, VR and The European Community FP7 2007-2013, under the Socio-economic Sciences and Humanities programme. My thanks also to Professor Andrew Higson for his helpful comments on this article.

\section{References}

BFI (British Film Institute). 2014a. Statistical Yearbook 2014. http://www.bfi.org.uk/statisticalyearbook2014/

BFI. 2014b. British Film Certification: Schedule 1 to the Films Act 1985: Cultural Test Guidance Notes, Version March 2014. London: BFI.

Bondebjerg, Ib, and Eva Norvup Redvall. 2013. "Transnational Scandinavia?

Scandinavian Film Culture in a European and Global Context.” In Transnational Cinema in Europe, edited by Manuel Palacio and Jörg Türschmann, 127-146. Vienna: Universität Wien.

Cox, David. 2009. "Don”t Confuse Love with Style, Mon Chéri." Guardian Unlimited, May 11, 2009.

Dawtrey, Adam. 1995. “Government Withdraws from Eurimages UK.” Variety, December 4-10, 1995, p.35.

European Audiovisual Observatory. 2000-2014. Focus: World Film Market Trends.

Strasbourg: European Audiovisual Observatory.

European Commission. 2013. "Press Release: State Aid: Commission Adopts New Film Support Rules.” November 14, 2013. European Commission.

http://europa.eu/rapid/press-release_IP-13-1074_en.htm

Ezra, Elizabeth, and Terry Rowden. 2006. “Introduction.” In Transnational Cinema:

The Film Reader, edited by Elizabeth Ezra Terry Rowden, 13-14. Abingdon:

Routledge.

Higbee, Will, and Song Hwee Lim. 2010. "Concepts of Transnational Cinema: Towards

a Critical Transnationalism in Film Studies.” Transnational Cinemas 1 (1): 7-21. Higson, Andrew. 2011. Film England: Culturally English Filmmaking since the 1990s. London: IB Tauris. 
Higson, Andrew, and Richard Maltby, eds. 1999. 'Film Europe' and 'Film America': Cinema, Commerce and Cultural Exchange 1920-1939. Exeter: University of Exeter Press.

Hill, John. 2012. “This is for the Batmans as well as the Vera Drakes': Economics, Culture and UK Government Film Production Policy in the 2000s.” Journal of British Cinema and Television 9 (3): 333-356.

Hjort, Mette. 2009. “On the Plurality of Cinematic Transnationalism.” In World Cinemas, Transnational Perspectives, edited by Nataša Durovicová and Kathleen Newman, 12-33. New York: Routledge.

Hoskins, Colin, Stuart McFadyen, Adam Finn, and Anne Jackel. 1995. "Film and Television Co-production: Evidence from Canadian-European Experience.” European Journal of Communication 10: 221-243.

House of Lords Select Committee on Communication. 2010. The British Film and Television Industries - Decline of Opportunity? Volume II: Evidence (HL Paper 37-II). London: Stationary Office.

Jäckel, Anne. 1996. "European Co-Production Strategies: The Case of France and Britain.” In Film Policy: International, National and Regional Perspectives, edited by Albert Moran, 85-100. Abingdon: Routledge.

Jäckel, Anne. 1997. "Cultural co-operation in Europe: the case of British and French cinematographic co-productions with Central and Eastern Europe.” Media, Culture and Society 19: 111-120.

Jones, Huw D. Forthcoming. "UK/European Co-productions: The Case of Ken Loach". Journal of British Cinema and Television.

Kanzler, Martin. 2008. “The Circulation of European Co-Productions and Entirely National Films in Europe 2001 to 2007." Report prepared for the Council of Europe Film Policy Forum co-organised by the Council of Europe and the Polish Film Institute, Krakow, 11-13 September 2008. http://www.coe.int/t/dg4/cultureheritage/culture/film/paperEAO_en.pdf

Liz, Mariana. 2015. "From Co-Production to the Euro-pudding." In The Europeanness of European Cinema: Identity, Meaning, Globalization, edited by Mary Harrod, Mariana Liz and Alissa Timoshkina, 73-86. London: I. B. Tauris.

Macnab, Geoffrey. 2013. "UK Industry Cheers Tax Break Changes.” Screen Daily, December 5, 2013. http://www.screendaily.com/territories/uk-ireland/ukindustry-cheers-tax-break-changes/5064369.article 
Morawetz, Norbert, Jane Hardy, Colin Haslam, and Keith Randle. 2007. "Finance, Policy and Industrial Dynamics - The Rise of Co-productions in the Film Industry." Industry and Innovation 14:4: 421:443.

Murray, Jonathan. 2012. "Blurring Borders: Scottish Cinema in the Twenty-First Century." Journal of British Cinema Television 9 (3): 400-418.

Pardo, Alejandro. 2007. "Spanish Co-productions: Commercial Need or Common Culture? An Analysis of International Co-Productions in Spain from 2000 to 2004.” In Zoom Out: Crossing Borders in Recent European Cinema, edited by Sandra Barriales-Bouche and Marjorie Attingnol Salvodon, 89-127. Newcastle: Cambridge Scholar Publishing.

Perry, Simon. 2014. "Why the UK is Missing Out on Co-production." Screen Daily, March 11, 2014. http://www.screendaily.com/comment/why-the-uk-is-missingout-on-co-production/5068494.article

Porter, Vincent. 1984. "European Co-productions: Aesthetic and Cultural Implications." Journal of Area Studies 6 (12): 6-10.

Shaw, Deborah. 2013. "Deconstructing and Reconstructing Transnational Cinema." In Contemporary Hispanic Cinema: Interrogating Transnationalism in Spanish and Latin American Film, edited by Dennison Stephanie, 47-66. Woodbridge: Tamesis.

Smith, Justin. 2010. "Une Entente Cordiale? - A Brief History of the Anglo-French Film Coproduction Agreement, 1965-1979." In Je t'aime... moi non plus: Franco-British Cinematic Relations, edited by Lucy Mazdon and Catherine Wheatley, 51-66. New York: Berghahn Books.

The Writing Studio. 2015. 'The Art of Writing and Making Films: Unhitched.' Accessed April 25, 2015. http://www.writingstudio.co.za/page1502.html Townsend, Nathaniel. 2014. Working Title Films and Transatlantic British Cinema. PhD diss., University of York.

Tutt, Louise. 2011. "How to Become a Spy Classic.” Screen Daily, December 8, 2011. http://www.screendaily.com/how-to-tailor-a-spy-classic/5035553.article 


\section{Figures}

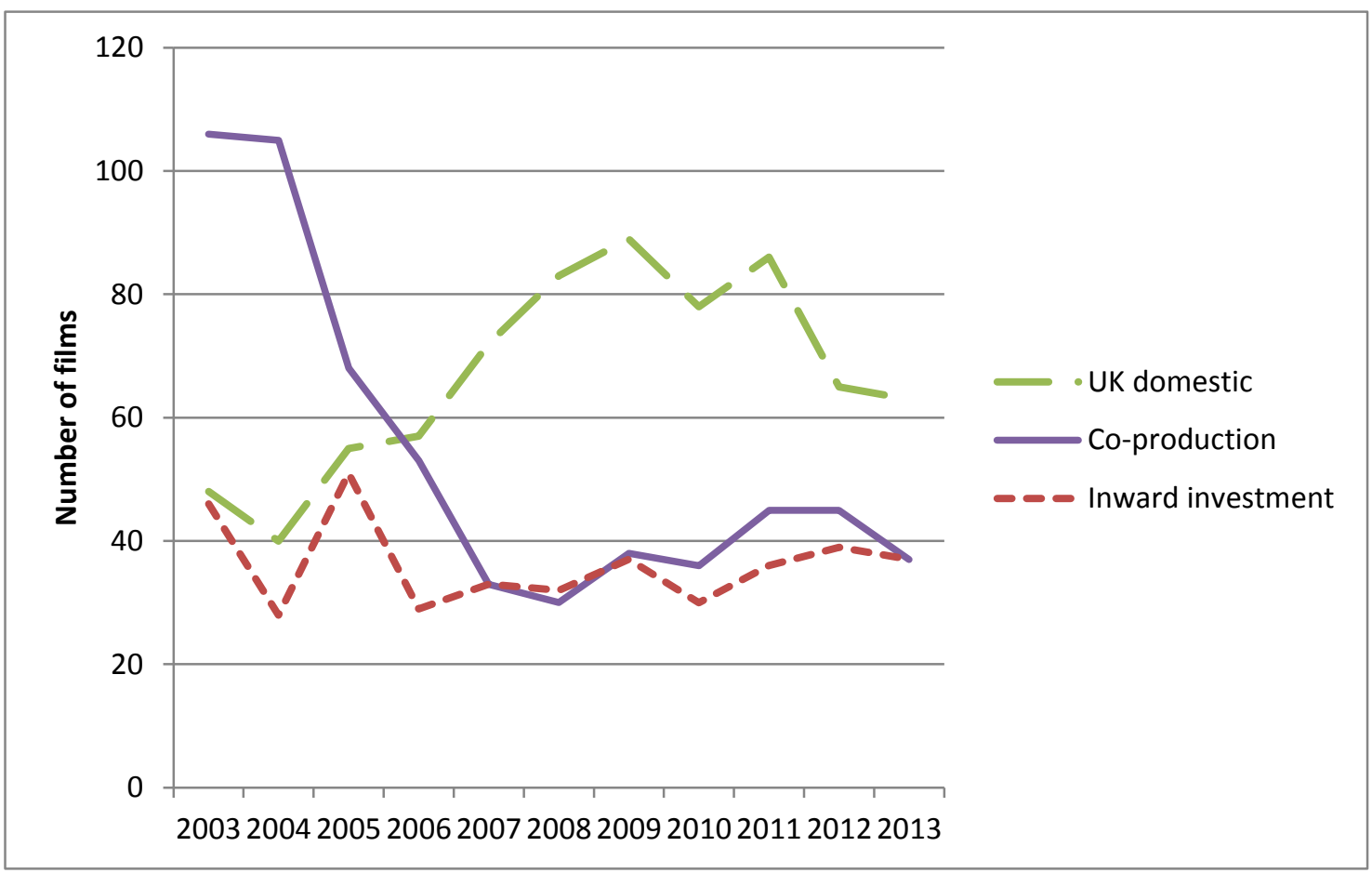

Figure 1. Number of feature films produced in the UK, 2003-13. Source: BFI 2014a: 182

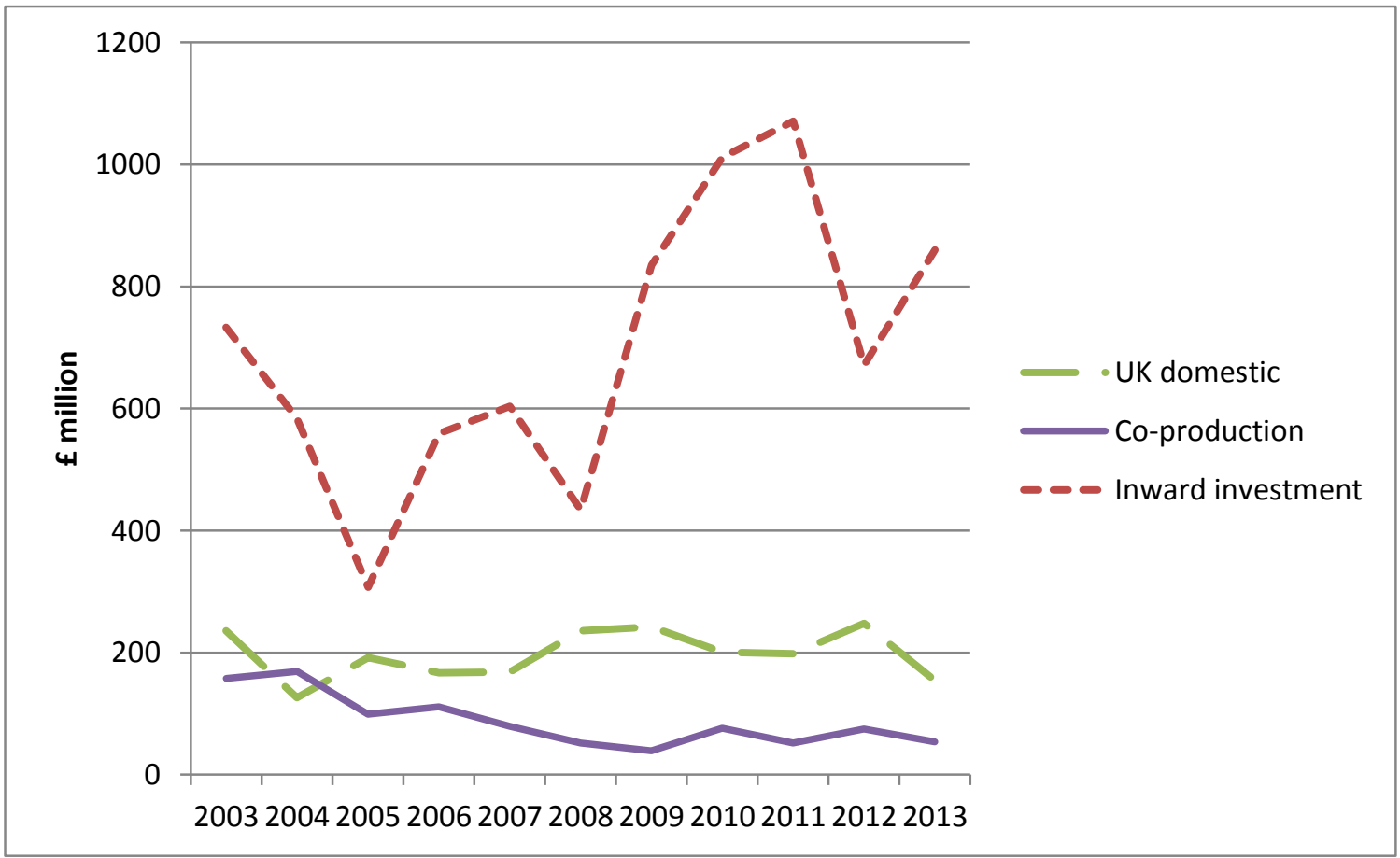

Figure 2. UK spend on feature films produced in the UK, 2003-13, £ million. Source: BFI 2014a: 180 


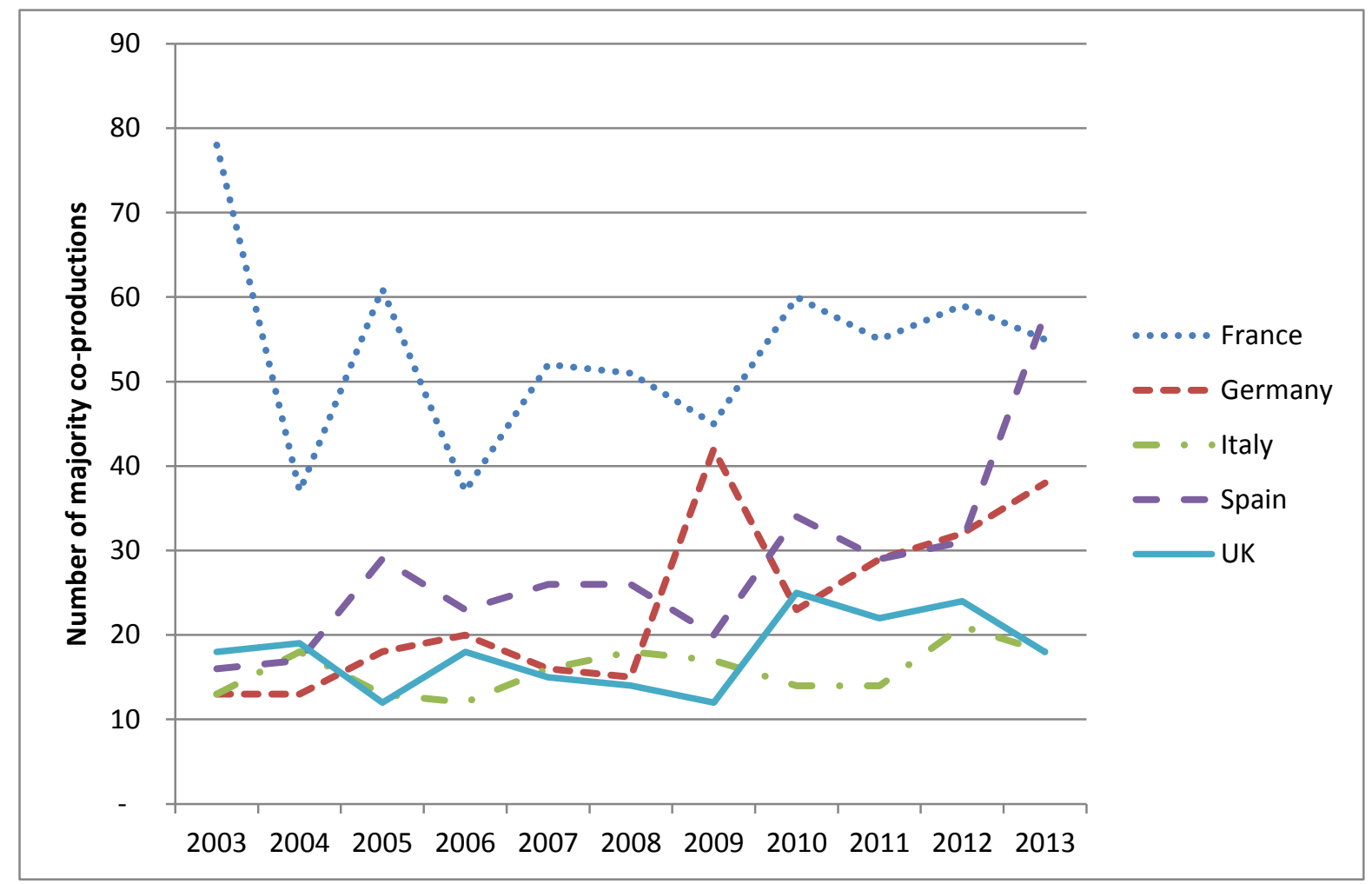

Figure 3. Number of majority co-productions in the EU"s "Big Five", 2003-2013. Source: European Audiovisual Observatory Focus: World Market Trends 20042014. 
Tinker Tailor Soldier Spy (UK / DE / FR) The Duchess (UK / FR / IT)

The Brøken (UK / FR)

The Last King of Scotland (UK / DE) Berberian Sound Studio (UK / DE) Route Irish (UK / FR / IT / BE / ES) Almost Adult (UK / DE) Jump (UK / IE) Revolver (UK / FR) Dreams of a Life (UK / IE) Wah-Wah (UK / FR)

The Tournament (UK / BG) The Best Man (UK / HU / DE) Solomon Kane (UK / CZ / FR)

Flawless (UK / LU)

The Mighty Celt (UK / IE)

Love and Other Disasters (UK / FR)

Mister Lonely (UK / FR / IE / US) Peter and the Wolf (UK / PL / CH / NO)

Chalet Girl (UK / DE / AT) AVERAGE

Turtle: The Incredible Journey (UK / DE / AT)

Guy X (UK / CA / IS)

Highlander: The Source (UK / LT)

The Flying Machine (UK / PL / NO) Joy Division (UK / HU / DE)

Four Last Songs (EN)

360 (UK / AT / FR / BR)

Fade to Black (UK / IT / SB)

L'illusioniste (UK / FR)

Chéri (UK / FR/ DE)

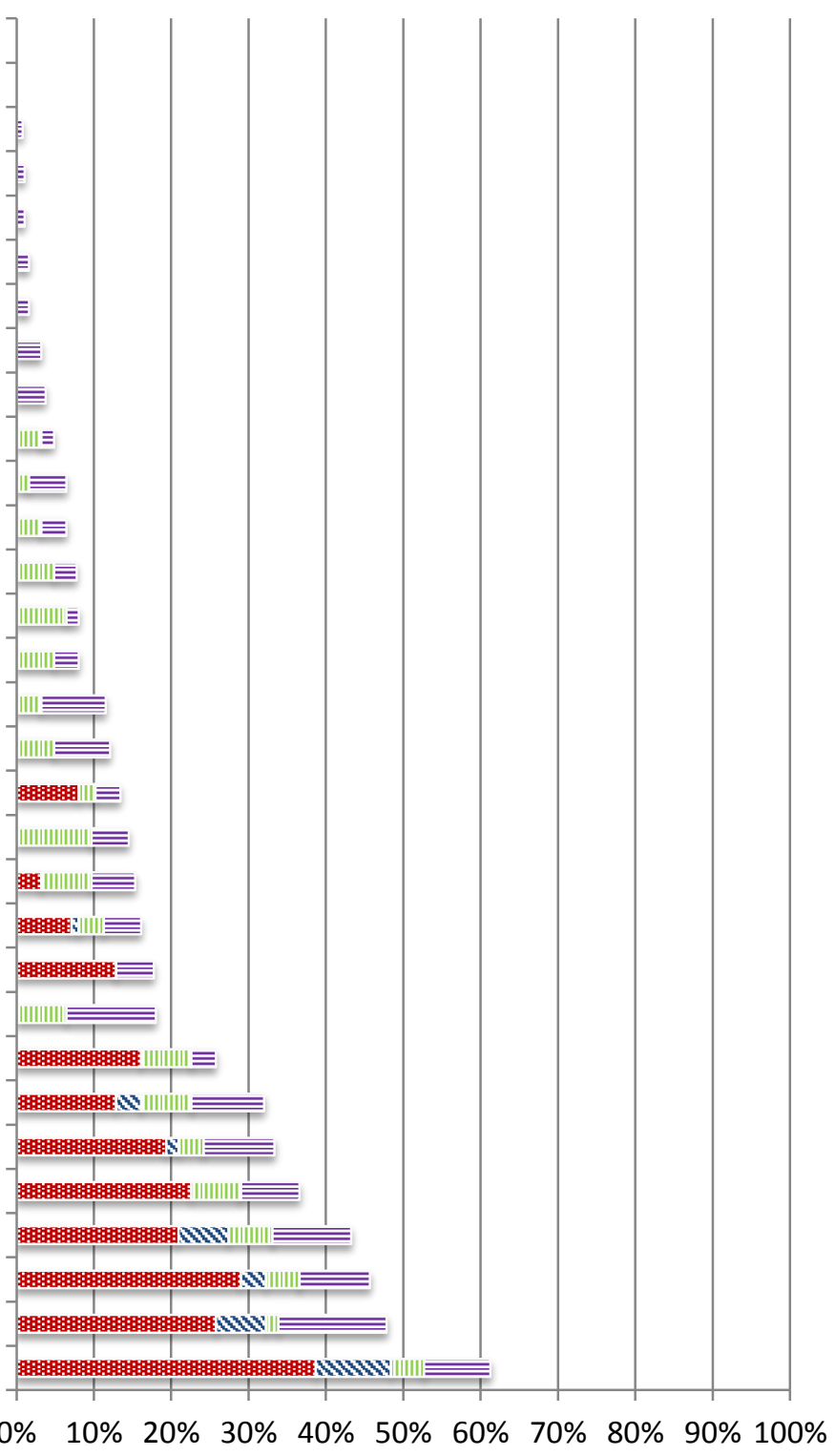

隐Cultural content $\approx$ Cultural contribution $\quad$ III Cultural hub $\equiv$ Cultural practitioners

Figure 4. Creative input (\%) of the European co-production partner(s) within a random sample of 30 UK/European co-productions, 2005-12. Based on the BFI's Cultural Test for film. 


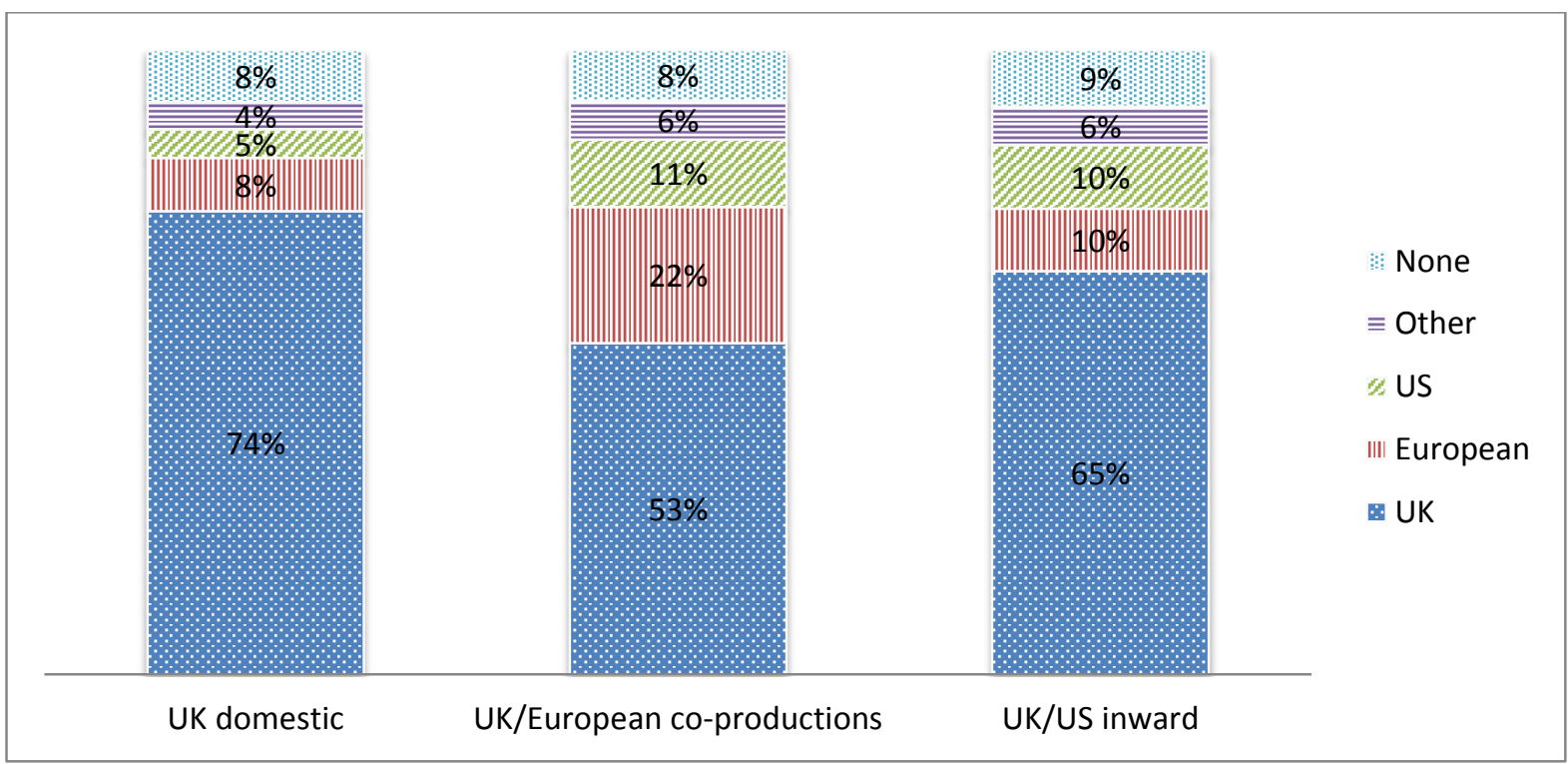

Figure 5. Average creative input (\%) for British films by production category, 2005-12. Based on the BFI's Cultural Test of film.

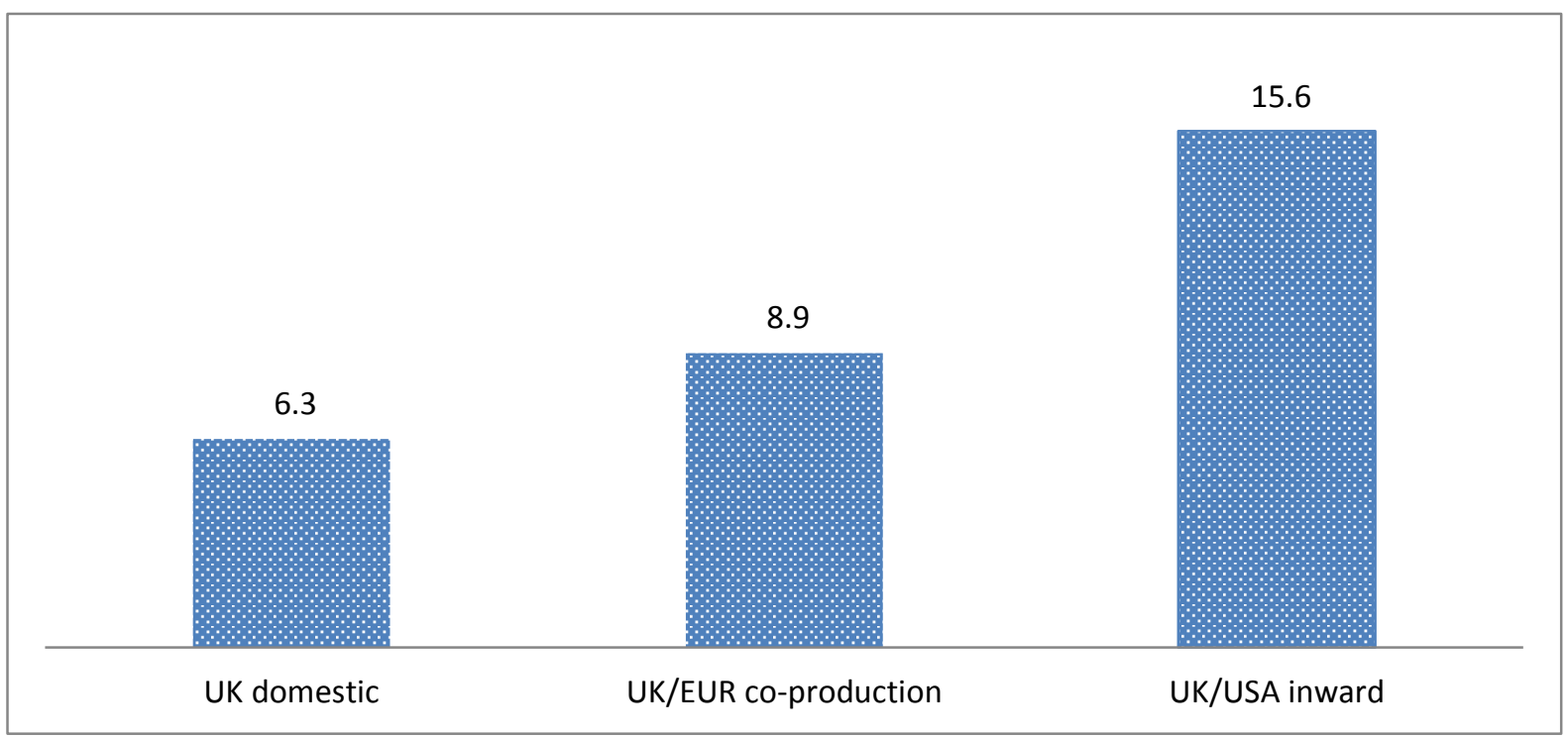

Figure 6. Average (mean) circulation of British films by production category. Source: LUMIERE/BFI 2014 


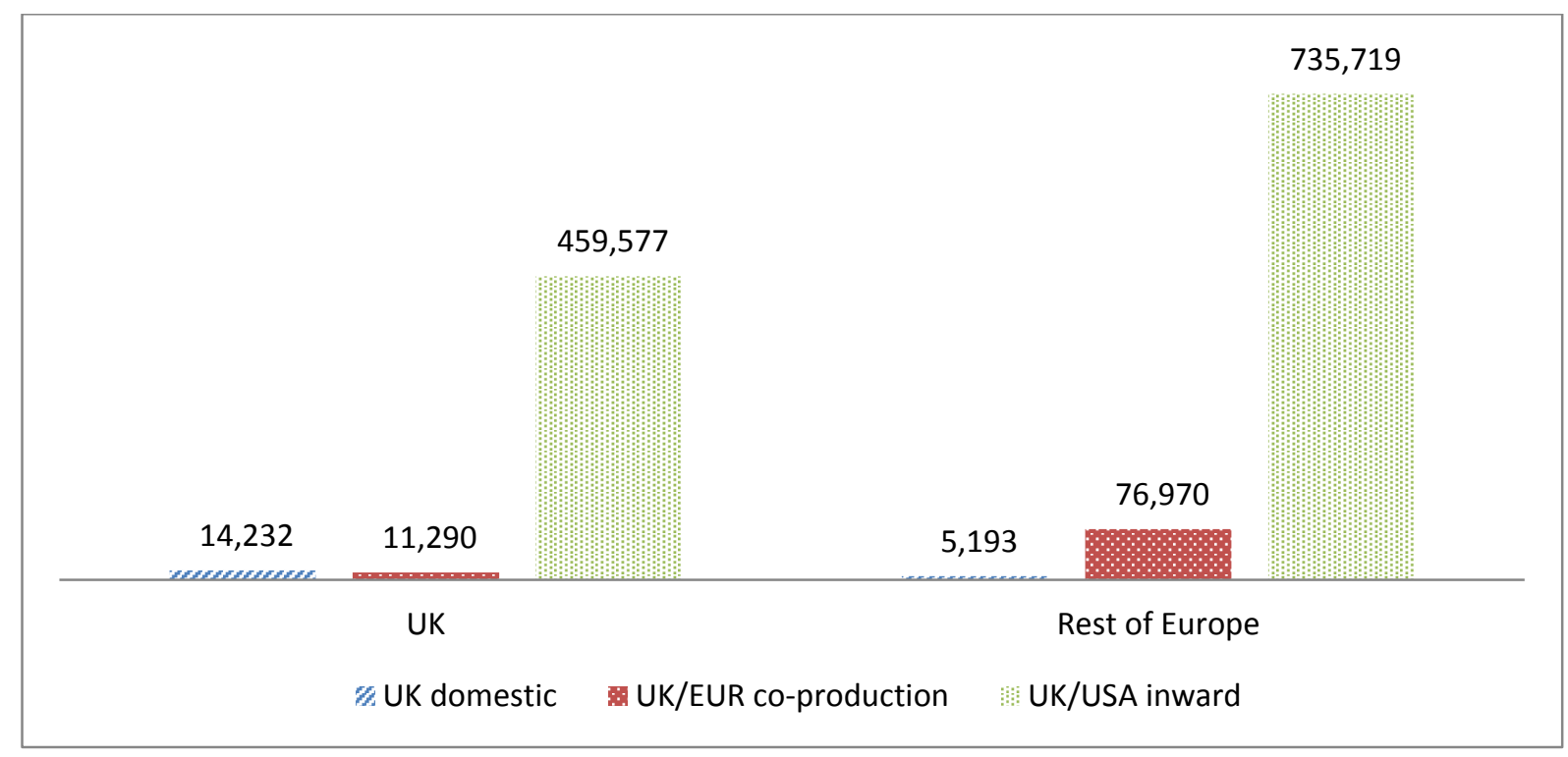

Figure 7. Average (median) performance of British films by production category. Source: LUMIERE/BFI 2014

${ }^{1}$ The cultural test is a points-based test where projects need to achieve 16 out of a possible 31 points to qualify as 'British'. It comprises of four sections: cultural content (up to 16 points); cultural contribution (up to 4 points); cultural hubs (up to 3 points); and cultural practitioners (up to 8 points). http://www.bfi.org.uk/film-industry/british-certification-taxrelief/cultural-test-film

${ }^{2}$ Data from the 'Transformation and Tradition in Sixties British Cinema' research project. https://60sbritishcinema.wordpress.com/about/

${ }^{3}$ The European Convention on Cinematographic Co-production is overseen by the Council of Europe, an international organisation promoting co-operation between European countries in the areas of legal standards, human rights, democratic development, the rule of law and cultural co-operation. The Council of Europe has 47 member states and is a separate organisation to the European Union, with which it is often confused. http://conventions.coe.int/Treaty/Commun/QueVoulezVous.asp?NT=147\&CL=ENG

${ }^{4}$ This article focuses on majority UK co-productions - i.e. films where the UK partner is recognised as the lead or majority producer. It will not consider minority UK coproductions, where the UK partner is recognised as a minority co-producer.

${ }^{5}$ Britain may be seen as part of Europe politically, geographically and culturally. However, for the purposes of this article, 'Britain' and 'Europe' will be referred to as distinct entities. 
${ }^{6}$ BFI film database (accessed November 6, 2014).

www.bfi.org.uk/sites/bfi.org.uk/files/downloads/bfi-film-high-end-tv-and-animationseries-production-in-uk-2003-2013-2014-10-06.xls

${ }^{7}$ LUMIERE database (accessed November 6, 2014). http://lumiere.obs.coe.int/web/search/

${ }^{8}$ The UK currently has eleven active bilateral co-production treaties with: Australia, Canada, China, France, India, Israel, Jamaica, Morocco, New Zealand, Occupied Palestinian Territories and South Africa. A bilateral treaty with Brazil is forthcoming. The European Convention on Cinematographic Co-production applies to 43 of the 47 member states of the Council of Europe. http://www.bfi.org.uk/film-industry/british-certification-taxrelief/co-production

${ }^{9}$ For this reason there is an argument that co-productions are more effective culturally and commercially when they are not made under the auspices of bilateral treaties (see Jäckel 2007)

${ }^{10}$ www.bfi.org.uk/sites/bfi.org.uk/files/downloads/bfi-film-high-end-tv-and-animation-seriesproduction-in-uk-2003-2013-2014-10-06.xls

${ }^{11}$ According to Murray (2012), Sigma's partnership with Zentropa illustrates how Scotland - in the period since political devolution in 1999 - has begun to develop its own distinct film culture through building on cultural affinities with other small European nations.

${ }^{12}$ For example, whereas the BFI database defines the Danish-language drama After the Wedding/Efter brulluppet (2006) as a UK/Denmark co-production, LUMIERE classifies it as a Demark/UK co-production. Only films defined as majority UK co-productions in both the BFI database and the LUMIERE database were included in the final dataset.

${ }^{13}$ Where two or more countries could both claim a point (e.g. the three lead actors came from Britain, France and Germany) the point would be split proportionately. With regard to language, accent and dialogue were also taken into account. So, for example, if characters spoke American English the points would go to America.

${ }^{14}$ To qualify as 'British' films need to score 16 points or more in terms of their British creative input.

${ }^{15}$ The dataset includes 313 UK domestic features, $64 \mathrm{UK} /$ European co-productions and 72 UK/US inward investment features. Admissions came from the LUMIERE database. Production categories were determined using the BFI and LUMIERE database.

${ }^{16}$ Budgets were obtained using the Internet Movie Database (IMDb). Accessed November 6, 2014. http://www.imdb.com/

${ }^{17}$ Genres were obtained using IMDb. Accessed November 6, 2014.

${ }^{18}$ Data on MEDIA distribution support for British films 2007 to 2013 was obtained with permission from the European Commission. 